\title{
SUSTAINABLE AGRICULTURAL PARADIGM OF MOUNTAIN-OASIS-ECOTONE-DESERT SYSTEM IN INLAND MANASI RIVER BASIN, XINJIANG PROVINCE, NORTHWEST CHINA
}

\author{
Huiming Liu ${ }^{1}$, Weiming Chen ${ }^{2}$, Xiaobin Dong ${ }^{1, *}$, Xinshi Zhang ${ }^{1}$ \\ ${ }^{1}$ College of Resources Science \& Technology, Beijing Normal University, Beijing P.R. China \\ 100875 \\ 2 State Key Laboratory of Resources and Environmental Information System, Institute of \\ Geographic Sciences and Natural Resources Research, Chinese Academy of Sciences, \\ Beijing P.R. China 730000 \\ * Corresponding author, Address:College of Resources Science \& Technology, Beijing Normal \\ University, Beijing P.R. China 100875, Tel: +86-10-58802854, Fax: +86-10-58802854, \\ Email:dongxb@ires.cn
}

Abstract: Manasi River basin is located in the north foot of Tianshan Mountain, south edge of Zhunger Basin, central-north Xinjiang province, with typical arid features of northern China. As the pressure on water resources in Manasi river basin is mounting because of rapid economic development, its conservation becomes ever more important. Climate change is another major threat to the future of water resources of Manasi river basin. How the water resource changes in Manasi river basin caused by glacial ablation, will affect the typical mountain-basin terrestrial ecosystems and agricultural production in Manasi river basin? What can we cope with the ecological issues caused by glacial ablation? In this paper we show how the water-saving stratagem such as constructing reservoir in the mountainous region, building water pipes and generalizing water-saving technology in upper, middle and lower reaches can be used in combination with the potential of water-saving resources, and build up sustainable agricultural paradigm of mountain-oasis-ecotone-desert system to coping with the glacier retreat and ablation. The potential of water-saving in study area were calculated which presumed that if mountainous reservoirs and water pipes were built and water-saving technology were adopted, $3.46 \times 108 \mathrm{~m} 3$ irrigating water could be saved one year in these oases. The optimized eco-productive paradigm for mountain-basin system in Manasi river basin is proposed in desertification controlling, constructing artificial

Please use the following format when citing this chapter:

Liu, H., Chen, W., Dong, X. and Zhang, X., 2009, in IFIP International Federation for Information Processing, Volume 293, Computer and Computing Technologies in Agriculture II, Volume 1, eds. D. Li, Z. Chunjiang, (Boston: Springer), pp. 197-207. 
grassland in the oasis is the measure to protect vegetation in the downstream desert in Manasi river basin, and stopping grazing or forbidding grazing in the downstream of serious degradation in Manasi river basin.

Keywords: the optimized eco-productive paradigm, groundwater, land use change, oasis, runoff, Manasi River watershed

\section{INTRODUCTION}

The complex of mountain-basin terrestrial ecosystems, or mountain-basin system (MBS) for short, in the north of the Tianshan Mountains, Manasi river basin, consists of mountain vegetation vertical belt system and concentric circular vegetation (geologic and geomorphic) system of desert basin. The MBS contains three "circles": montane, piedmont fan and alluvial plain, including nine belts. Viz. alpine belt, montane forest-grassland belt, low-mountain desert belt, gravel gobi desert belt, agricultural oasis, marginal belt of diluvial fan, alluvial desert plain, sandy desert belt, and lake. The above-mentioned zonation is the most essential existence and functional pattern of those precious natural resources(Zhang, 2001).

The sustainable agricultural paradigm of mountain-oasis oasis/desert ecotone-desert system (MOED), which is gradually demonstrated, and based on the profound scientific foundation, can be used as ecological conservation, reconstruction and the adjustment of agricultural structure. It is the presentation of an irresistible rule of the nature and, also, the gsystem of ecological conservation and land use. The MBS is its basic frame(Zhang, 2000). Thus, the establishment of a sustainable agricultural system and an optimized land use/cover structure and patterns in Manasi river basin, which aimed at ecological conservation, may be possible.

As the pressure on water resources in Manasi river basin is mounting because of rapid economic development, its conservation becomes ever more important. Population growth, increased incomes and urbanization have joined forces and agriculture cannot keep up with the increasing demands of this emerging, new community. To sustain the increased demand for more and diverse agricultural products in Manasi river basin, it is ineuidance vitable that the acreage of irrigated area will increase over the years.

Climate change is another major threat to the future of water resources of Manasi river basin. Widespread accelerated glacier retreat and melt water in stream flow timing, from spring to winter, are caused by climate change. There are serious concerns about the alarming rate of retreat of glaciers. In the short run the glacier melt may increase water availability, but eventually 
the base flow from glaciers will cease(Shi, et al., 1990; Shi, et al., 1999; IPCC, 2001). In general, Temperature rise and meltwater increase during the first half of this century are favorable to the development of irritated agricultural and economic growth of Manasi river basin in the early and middle part of this century, which is located in in the north slopes of the Tianshan Mountains, southern margin of the Junggar Basin(Shi, 2001; Lai, 1986). However, after peak value of meltwater in the later part of this century, meltwater curtailment because of glacier Shrinkage, will intensify the lack of water resource.

How the water resource changes in Manasi river basin caused by glacial ablation, will affect the typical mountain-basin terrestrial ecosystems and agricultural production in Manasi river basin? What can we cope with the ecological issues caused by glacial ablation? And what can we improve the management of water resource utilization and agricultural structure to adapt to increase of glacial melt water?

In this paper we show how the water-saving stratagem such as constructing reservoir in the mountainous region, building water pipes and generalizing water-saving technology in upper, middle and lower reaches can be used in combination with the potential of water-saving resources, and build up sustainable agricultural paradigm of mountain-oasis-ecotone- desert system to coping with the glacier retreat and ablation.

\section{STUDY AREA}

\subsection{Geographic location}

Manasi river basin which belongs to Shihezi city, Shawan and Manasi countries in administrative division, is located in north of Tianshan Mountain, South Margin of Junggar Basin. It is between $43^{\circ} 27^{\prime}-45^{\circ} 21^{\prime} \mathrm{N}$ 、 $85^{\circ} 01^{\prime}-86^{\circ} 32^{\prime} \mathrm{E}$, total area $2.29 \times 104 \mathrm{~km}^{2}$, mountain and plain in half. 


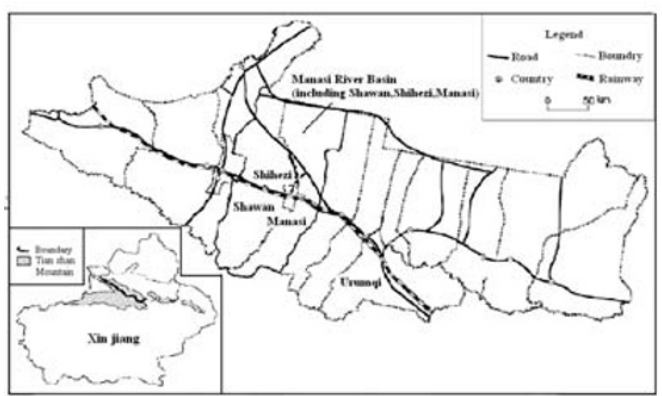

Fig. 1 Administratively Area of Oasis Economy Belt of Northern Slope of Tianshan Mountain in Xinjiang

\subsection{Terrain and landforms}

The terrain of Manasi river basin is higher in the southern rather than the northern part. The highest elevation is $5,242.5 \mathrm{~m}$ in the southern mountainous area of Manasi river basin. The permanent ice and snow covered areas are distributed above a $3,900 \mathrm{~m}$ attitude of high and extra-high mountain areas. The distribution areas of alpine cushion vegetation and lichen are about 3,200$3,900 \mathrm{~m}$ in altitude. Alpine meadow with an altitude of $2,300-3,200 \mathrm{~m}$ above sea level, and spruce forest with an altitude of $1,650-2,850 \mathrm{~m}$ above sea level. Mountain grassland and desert grassland distribute in the elevation of 1,100 $1,650 \mathrm{~m}$ and $800-1,100 \mathrm{~m}$ above sea level, respectively. The plain area below $800 \mathrm{~m}$ altitudes are the eco-tone between oasis and desert. According to vertical and horizontal position, the spatial position is in sequence of temperate desert grassland (the alluvial fan, elevation 410-800m), temperate meadow-swampsaline vegetation (the marginal belt, elevation $370-410 \mathrm{~m}$ ), temperate desert (the alluvial plain, elevation $350-370 \mathrm{~m}$ ), temperate sand vegetation (the plain and desert, elevation $260-350 \mathrm{~m}$ ), temperate salt-marsh vegetation (the lacustrine deposit plain), from piedmont to the in-depth research of the desert. Relying on Manasi river basin, oasis on the forms of belt and patch is distributed in the piedmont alluvial-pluvial fan, alluvial fan marginal belt, and alluvial plain.

\subsection{Climate}

The climate of Manasi river basin is of continental climatic type. The annual and daily differences in temperature are big. The annual mean temperature is $6.6^{\circ} \mathrm{C}$, the annual mean precipitation $110-200 \mathrm{~mm}$, accumulated temperature of more than $10^{\circ} \mathrm{C} 2,400-3,500^{\circ} \mathrm{C}$, annual average wind speed $1.7 \mathrm{~m} / \mathrm{s}$. The water resources in Manasi river basin is abundant, which has five inland rivers, in the sequence of Taxi river, Manasi river, Ningjia river, Jingou river, Bayingou river, from east to west. The five inland rivers which originated from the northern foot of Tianshan mountain, 
and flow into Junggar Basin. The total amount of water resource in Manasi river basin is $25.73 \times 10^{8} \mathrm{~m}^{3}$, and about $22.91 \times 10^{8} \mathrm{~m}^{3}$ of stream flow available for development and utilization, in addition, there are also $11.97 \times$ $10^{8} \mathrm{~m}^{3}$ of groundwater resources non-repeated with Surface Water in the piedmont plains.

\section{THE LAND USE CHANGES AND WATER RESOURCES IN MANASI RIVER BASIN}

Manasi river basin is located in north of Tianshan Mountain, South Margin of Junggar Basin. The natural environmental of Manasi river basin is a complex of mountain - basin terrestrial ecosystems, or mountain-basin system (MBS) for short. The stability of oasis in Manasi river basin is determined by the ecosystem structures, functions and ecological process, and directly related to sustainable development of regional society and economy. The condition of land use changes and water resources are as follows.

\subsection{The processes of land use changes in Mnasi river basin from 1949 to 2001}

Based on " $3 \mathrm{~S}$ " technology and images, Chen Weiming et al. studied the spatial and temporal changes of oasis in almost over 50 years from 1949 to 2001, by using the datasets of 1:100, 000 topographic map(1962), Landsat MSS(1976/06/15), TM(1989/08/09), ETM(1999/07/04, 2001/08/15), and get the conclusions(Tab.1):

Tab.1 Area Change of Oasis Landscape over Last 50 Years in Manas River Basin (Chen Weiming et al.2005)

\begin{tabular}{lcccccc}
\hline Land use Types & 1949 & 1962 & 1976 & 1989 & 1999 & 2001 \\
\hline Farmland & 156.385 & $2,750.458$ & $3,639.491$ & $4,234.008$ & $4,427.377$ & $4,568.254$ \\
Artificial Garden & - & 0.434 & 15.632 & 29.660 & 29.598 & 30.905 \\
Artificial Reservior & - & 7.319 & 48.335 & 81.108 & 78.903 & 107.642 \\
Town & - & 18.706 & 22.481 & 59.359 & 70.536 & 75.713 \\
Village & - & 169.133 & 186.563 & 206.647 & 245.115 & 256.845 \\
Building & - & 0.0 & 0.0 & 0.427 & 1.004 & 2.717 \\
Area of oasis & 156.385 & $2,946.050$ & $3,912.502$ & $4,611.209$ & $4,852.533$ & $5,042.076$ \\
\hline
\end{tabular}


As Table 1 showed, the expansion between oasis and farmland are synchronized and agriculture is the leading industry in Manasi river basin. The process of oasis extension is divided into two stages.

The rapid expansion (1949-1976): with rapid expansion of original oasis and exploitation of new opening oasis, they are joined by each other; the steady development of oasis (1976-2001): the outline of oasis from north to south is not extended, and the main changes are in inner artificial oasis. Saline land mostly distributed in low ground of the desert margins, which has been the concentration area of salinity (Chen et al., 2005).

\subsection{The processes of land use changes in Mnasi river basin from 1949 to 2001}

\section{The runoff forming district (montane fan) in Manasi river basin}

Mountainous area is the flow concentration area in Manasi river basin, the mean annual precipitation is $700-1000 \mathrm{~mm}$, and the area of glaciers is $1228 \mathrm{~km}^{2}$. The mean annual precipitation of the mountainous area which is below the glaciers is $408 \mathrm{~mm}$ and area is $6006 \mathrm{~km}^{2}$. Mountainous area has the function of water resource conservation and ecological maintenance. The mean forest cover rate is only $5.5 \%$ and forest density has already decreased from $0.9 \%$ to $0.3 \%$. The area of dominant specie P.schrenkiana is only $237.5 \mathrm{~km}^{2}$ and the cover rate is $2.8 \%$, and the rest forest is the secondary plantation with low water resource and ecological sustainable function. Meanwhile, vegetation degradation caused by forest and grass destroy, overloading and overgrazing, diseases and insect pests, soil erosion are ubiquity in mountainous area..

\section{Runoff-dissipating district (piedmont and alluvial plain) in Manasi river basin}

Piedmont fan is the distribution in oasis and runoff-dissipating district, and it is the distributed areas of towns, industry, and agriculture, track network, where it is the core area of using high efficient artificial technology to convert water resources and creating social wealth. The area of oasis is $6,534 \mathrm{~km}^{2}$. To the effective and reasonable utilization of runoff from mountainous area, people traditionally depended on developing water conservancy, hydropower and irrigation facilities. At present, the total length of built-up channel is $22,296 \mathrm{~km}$, the amount of reservoir more than thirty. The irrigating water from mountainous area is only thirteen billion $\mathrm{m}^{3}$, the utilization Ratio of water resources from mountainous area is $57 \%$, repeated utilization ratio 9.1 billion $\mathrm{m}^{3}$, and annual regulating water storage capacity accounts for $17.4 \%$ of annual runoff..

\section{Sandy desert district in the downstream of Manasi river basin}


The area of sandy desert district in the downstream of Manasi river basin is about $10,000 \mathrm{~km}^{2}$, and the annual precipitation is below $100 \mathrm{~mm}$. The amount of evaporation is about ten times higher than precipitation. The growth of desert vegetation depends on leakage water from the oasis, but these vegetations are the essential ecological barrier against the ecological disaster, such as dry-hot wind, sand flow, desertification, salinization and alkalization. Because of the extension of oasis and rapid increase of interception diversion, the amount of water resources in the down stream falling sharply, and even setting off. As the surface water over utilization and ground water excessive exploitation, underground water level decreases sharply, this causes Manasi lake shrinkage and lake level reducing even drying up. The pasture and meadow with high quality and yield in the plain successive disappeared, directly to the succession of desert or sparse vegetation landscape stages.

Desert is often taken as no any production and ecological function areas. Sparse desert vegetation is cut and destroyed a lot to result in sustainable deterioration of desert ecosystem. The ecological supplying water on desert grassland is little and not to sustain water demands of grassland and forest trees in the downstream of Manasi river basin. The deterioration of desert grassland in alluvial desert plain is resulted in the water resource deterioration which is the grassland depended on.

\section{SUMMARY AND CONCLUSIONS}

The main ecological and environmental problems that Manasi river basin are faced on, are divided into three kinds, which are all related to water resource.

The first kind is the trend of decreasing and degrading of forest and grassland in the runoff forming district of Manasi river basin, and forest coverage declining. The area of dominant species P.schrenkiana decreased a lot. It is urgent to prevent the deterioration of forest and grassland at prime tense and restore the function of water conservation.

The second kind is a large quantity of melt water caused by glacial ablation, and the contribution of the stream flow from glacial ablation is much greater. Farmland in the lower area is submerged, while the distribution range and area of saline land is increasing. The unreasonable irrigation in Manasi river basin resulted in secondary salinization and a lot of low middle yield field, even the abandonment of land use began to increase notably almost in the same time. Sandy desert belt along the lower marginal belt of oasis is the discharging area of saline-alkaline. In recent years, most 
drainage system of saline-alkaline opened into desert, which has become the concentration area of saline-alkaline and had important influence on the growth of psammophilous vegetation.

The third kind is the over grazing in the downstream of Manasi river basin, where it is the sandy desert belt. Over grazing obviously accelerates desertification in the downstream. Desert vegetation has a large amount of death, and the desert is significantly enlarging and moving towards south annually.

The forth kind are outstanding problems of insufficient regulation capability of reservoirs. The annual water storage capacity of Manasi river basin occupied $17.4 \%$ of the total runoff. A large amount of incoming water during flood season (late summer and autumn), almost wastes without utilization, but drought and water shortage during dry season (spring and early summer) are restricting seriously the food production and social economic development. Serious seepage canal system and background irrigation, and water diversion rate is lower than $50 \%$. High efficiency water saving methods of sprinkler irrigation, drip irrigation, and infiltration irrigation are not applied. The traditional extensive water diversion leads to the fact that water resources are wasted, the elevation of groundwater level and salinization of soil on large range.

\section{THE OPTIMIZED ECO-PRODUCTIVE PARADIGM FOR MOUNTAIN-BASIN SYSTEM IN MANASI RIVER BASIN}

What can we improve the management of water resource utilization and agricultural structure to adapt to increase of glacial melt water? How much water volume can water saving measures be saved? How much potential does water saving measures have? They are important strategies of the above ecological problems and water resource management of the whole river basin. They are also the important basis on making river basin management mode and water management target.

\section{Banning grazing in mountainous belt of Manasi river basin and protecting water conservation forest (dominant species P.schrenkiana)}

The degeneration of ecological environment, such as vegetation degradation, soil erosion, diseases and insect pests, forest and grassland destroy, overloading and overgrazing, has been more serious.

The domain species, spruce forest distributed in altitude ranging from $1650 \mathrm{~m}-2850 \mathrm{~m}$, in mountainous area of Manasi river basin. Human disturbance to herbaceous layer is becoming more serious to cause great threats to natural regeneration of mountain forest. Meanwhile, disappearance 
of herbaceous plant caused the bare surface, which changed the land surface reflectance and caused soil water content decreasing. Mountainous forest could prevent dry hot air flow arising from desert. In recent years, the implementation of natural forest conservation protects woody plant but ignore herb plants, which are taken as one of the most important component of forest ecosystem. It is necessary for the whole recovery of forest ecosystem including herb plants and construction of valley forest.

According to the analysis of vegetation characteristics in different altitudes of Manasi river basin, the different countermeasures of recovery are performed: natural restoration of alpine meadow from the elevation of $2,300 \mathrm{~m}$ to $3,200 \mathrm{~m}$; natural restoration combined with artificial restoration of spruce forest from the elevation of $1,650 \mathrm{~m}$ to $2,850 \mathrm{~m}$, and mountain grassland from the elevation of $1,100 \mathrm{~m}$ to $1,650 \mathrm{~m}$.

\section{Improving high efficiency and intensive utilization of water resources}

1. Building up reservoirs in mountainous area and storage of melt water and runoff that are caused by global warming and glacial ablation

Analysis of reservoir's water-saving potential in mountainous: runoff and melt water almost appears in summer, and in the next decades, increasing of melt water and runoff cause water resources relative surplus in summer and deficiency in spring. Building up reservoirs in mountainous area to accumulate melt water and runoff and reducing evaporation loss of reservoirs in the desert plain, in order to supply more water resources, which will increase $15-20 \%$ water supply.

2. Building up water Pipeline to prevent evaporation and leakage

Analysis of water-saving potential of water conveyance system: Statistical value of canal-system water use efficiency is 0.57 ( $\mathrm{Li}$ et al, 2007), if it would have been 0.67 by canal seepage control, development of water conveyance pipe and decreasing evaportranspiration. There will be saving water 1.3 billion $\mathrm{m} 3$ in water conveyance system of Manasi river basin.

3. Extension of field water saving technology

Analysis of farmland water saving technology: the irrigating water from mountainous area is only thirteen billion $\mathrm{m} 3$, the utilization Ratio of water resources from mountainous area is $57 \%$. If the utilization ratio of water resources would be $67 \%$ which increases $10 \%$, the whole river basin will be saving 1.3 billion $\mathrm{m}^{3}$. Water repeated utilization ratio in the field is only 9.1 billion $\mathrm{m}^{3}$. If Water repeated utilization ratio would have been 10 billion $\mathrm{m}^{3}$ in the oasis, with developing salt water irrigation technology and cultivating halophytic vegetation, water resources would be saved 0.9 billion $\mathrm{m}^{3}$. Annual water storage capacity accounts for $17.4 \%$ of annual runoff. If it is increased to $27.4 \%$, water resources would be saved 1.26 billion $\mathrm{m}^{3}$. 
Combined with above three methods, water resources would be saved 3.46 billion $\mathrm{m}^{3}$.

\section{Desertification Controlling}

1. Desertification controlling in Manasi river basin should be based on water saving agriculture

Desertification controlling in downstream of Manasi river basin, implementation of normal supply water use in the oasis and desert grassland, should be based on water saving agriculture. Surface diversion is seriously excessive, but utilization efficiency of water is very low. The water efficiency in field canal system of irrigation is 0.57 . Because of the serious loss of water and low production efficiencies, energy consumption per unit GDP and agricultural water consumption is 6 times of national average level. The benefits of water consumption per $\mathrm{m}^{3}$ are a quarter of the country average level. Fully exploit potentialities of water would promote conservation of desert ecosystem.

2. Constructing artificial grassland in the oasis is the measure to protect vegetation in the downstream desert in Manasi river basin

A large amount of pasture is ingested in the downstream of Manasi river basin. Planting artificial grassland with high yield, improving forage output in the unit area, increasing supply of forage grass and feed, which decrease livestock number, grazing time and grazing pressure of desert grassland, finally achieved the ecological exchanges from natural grassland grazing to artificial grassland barn feeding.

3. Stopping grazing or forbidding grazing in the downstream of serious degradation in Manasi river basin

We could adopt protect first and prevent grassland from further degradation as the dominant factor and proper light grazing in desert grassland. Control grazing period and grazing capacity, and relief the pressure of grassland grazing.

\section{ACKNOWLEDGEMENTS}

Financial support for this work was provided by National Natural Science Funds Key Project NO. 40435014.

\section{REFERENCES}

Chen Weiming, Zhou Chenghu, Liu Haijiang, et al. The study on oasis expansion and ecological evolution in Manasi river basin in recent 50 years. Science in China Series D: Earth Sciences, 2005, 35 (11): 1074-1086. 
IPCC, 2001. Climate change 2001: the scientific basis. Contribution of Working Group I to the Third Assessment Report of the Intergovernmental Panel on Climate Change, Cambridge University Press, Cambridge.

Lai Zuming, Cao Zhentang, Liu Chaohai, et al . Glacier Inventory of China , III, Tianshan Mountains ( Interior Drainage Area of Junggar Basin in Northwest) [M]. Beijing: Science Press, 1986.

Li Yuyi, Liu Hongdong, Zhang Fenghua. et al. Assessment on the effect of irrigation technology on soil salinization in Manas River valley, Xinjiang. Journal of China Agricultural University, 2007, 12 (1): 22-26.

Shi Yafeng, Liu Shiyin. Estimation of the response of glaciers in China to the global warming in the 21st Century [J] . Chinese Science Bulletin, 1999, 45 (7): 668-672.

Shi Yafeng, Ren Jiawen. Glacier recession and lake shrinkage indicating a climatic warming and drying trend in Centra Asia [J]. Annals of Glaciology, 1990, 14: 261-265.

Shi Yafeng. Estimation of the Water Resources Affected by Climatic Warming and Glacier Shrinkage before 2050 in West China. Journal of Glaciology and Geocryology, 2001, 23(4): 333-341.

Zhang Xinshi. Ecological Restoration and Sustainable Agricultural Paradigm of MountainOasis-Ecotone-Desert System in the North of the Tianshan Mountains. Acta Botanica Sinica, 2001, 43(12): 1294-1299.

Zhang Xinshi. The ecologic and economic function of grassland and its paradigm Sci Tech Rer, 2000, 146(8): 3-7. 